\title{
ENERGY-EFFICIENT ASSET MANAGEMENT FOR PROFESSIONAL LANDLORDS
}

\author{
Jan-Willem SMID ${ }^{1}$ and Nico NIEBOER ${ }^{2} \bowtie$ \\ 1 OTB Research Institute for Housing, Urban and Mobility studies, Delft University of \\ Technology, P.O. Box 5030, 2600 GA Delft, The Netherlands \\ E-mail: j.w.smid@tudelft.nl \\ 2 OTB Research Institute for Housing, Urban and Mobility studies, Delft University of \\ Technology, P.O. Box 5030, 2600 GA Delft, The Netherlands \\ E-mail: n.e.t.nieboer@tudelft.nl
}

Received 6 March 2007; accepted 30 November 2007

\begin{abstract}
CO}_{2}$ reduction by means of energy conservation is an important topic in many governmental environmental policies. As new construction accounts for a fraction of the total building stock, the energy performance of existing dwellings is of great importance. Professional landlords can play a major role in energy conservation, but there are indications that the large energy conservation potential in their housing existing stock is only exploited to a minor extent. This paper presents a method to implement the topic energy conservation in the asset management of professional landlords, in order to establish an integration of energy conservation in their maintenance and renovation practice. This method is described in relation to the asset management of Dutch social housing landlords, but may also be useful for other professional landlords. The method takes advantage of the European EPBD (Energy Performance of Buildings Directive).
\end{abstract}

KEYWORDS: Rented sector; Strategic asset management; EPBD; Label; Energy performance

\section{INTRODUCTION}

In 1997, the developed nations agreed in the Kyoto Protocol to limit their greenhouse gas emissions. The residential sector accounts for a significant part of the final energy consumption in the European Community and, therefore, the built environment is an important target of the governmental environmental policies resulting from the Kyoto Protocol.

In the Netherlands, much progress has been made in reducing $\mathrm{CO}_{2}$ emissions in new construction. However, annual new construction accounts with less than $1 \%$ for just a minor part of the total Dutch building stock. The percentage of annual new construction is equally low in other European countries. The existing building stock has a low energy performance caused by poor insulation and inefficient heating systems. The energy consumption in existing dwellings exceeds that of new dwellings by far and, therefore, a large potential in energy conservation is available in the existing building stock.

Professional landlords in the EU own a considerable share of the total housing stock. They

International Journal of Strategic Property Management

ISSN 1648-715X print / ISSN 1648-9179 online (C) 2008 Vilnius Gediminas Technical University

http://www.ijspm.vgtu.lt

DOI: 10.3846/1648-715X.2008.12.19-34 
could play an important role in fulfilling the commitments concerning the reduction of $\mathrm{CO}_{2}$ emissions following the Kyoto protocol, if they improve the energy performance of their housing stock.

Providing affordable housing for lower income groups, by keeping the energy bill for their tenants as low as possible, is in line with the main goals of professional landlords with a social objective. Additionally, improvement of the energy performance of the rented housing stock is an effective means to reduce fuel poverty (Healy and Clinch, 2004).

In spite of the financial barrier that professional landlords face when considering improvement of the energy performance of the stock, a growing number of Dutch social landlords invests in energy conservation. Anticipating on rising energy prices and tightening energy policies, these professional landlords have shifted their focus towards an increase of the market value of an energy efficient housing stock and towards the objective to decrease living costs of the lowest income groups.

Another incentive for professional landlords to invest in energy conservation is related to the enhanced comfort of living that usually results from insulation measures, such as reduced noise, decrease in condense or humidity and reduced cold air flows (Milne and Boardman, 2000; Egenhofer et al., 2006). Furthermore, energy-efficiency improvements in dwellings result in an increase of the overall health level of the dwelling (Milne and Boardman, 2000; Howden-Chapman et al., 2004).

In order to improve the energy performance of their asset efficiently and cost-effectively, professional landlords could incorporate the topic energy conservation in their asset management, thus ensuring an integration of considerations regarding energy conservation in the decision-making process from strategy development down to the operational level. This paper presents a method for professional land- lords to integrate energy conservation in their asset management strategies. The method is described in relation to the asset management of Dutch housing associations, which provide the vast majority of the social-rented homes in the Netherlands. However, the method may also be useful for other professional landlords.

The next section will elaborate on the potential for energy conservation in the social rented housing stock. After that, section 3 will go into the EC directive on the energy performance of buildings, which will have a major impact on the activities and strategies of housing associations. In section 4 , we describe the outline of strategic asset management and how it can be developed using 'labels' in the decision-making process. Section 5 presents the integration of energy-efficiency and EPBD energy labelling in strategic asset management. Section 6 presents three case studies of housing associations that have adopted energy-efficiency in their asset management and maintenance activities. This paper ends with a discussion and conclusions in section 7 .

\section{ENERGY CONSERVATION POTENTIAL IN THE RENTED HOUSING STOCK}

Commercial and social rented housing accounts for a significant segment of the housing sector in many European countries (Table 1). Depending on their main objective (social or commercial) and the housing system in each country, professional landlords are, to a certain extent, able to develop their housing stock according to their own goals and, therefore, could play a role in the success or failure of the governmental environmental policies.

In the EU-25 countries, the final energy consumption of households accounts for $26 \%$ of the total energy use, most of which is used for space heating (Wiesenthal et al., 2006). Consequently, the two main options to reduce energy consumption and $\mathrm{CO}_{2}$ emissions in 
dwellings are insulation of wall, glazing, roof and floor and efficient heating systems (Egenhofer et al., 2006). In particular insulation could be a very cost effective means for energy conservation in housing (Ecofys, 2005; Verbeeck and Hens, 2005). It shows that a significant cost effective energy conservation potential is present in the existing housing stock in the European countries (Petersdorff et al., 2005).

The energy conservation potential can even be high in housing segments that, generally speaking, have a good technical quality. A large part of the Dutch social housing stock, for example, has been built between the Second World War and the 1970s. In general, these homes are well maintained, but the energy performance of these dwellings is relatively low compared to today's standards (Ministry of VROM, 2002). For example, the insulation facilities in the social housing stock have significantly increased in the dwellings built after 1970. Still, from Table 2 we learn that a large energy conservation potential resulting from insulation is available in the Dutch social housing stock. Moreover, the potential is

Table 1. Division of the housing stock by tenure

\begin{tabular}{|c|c|c|c|c|}
\hline Country & Owner-occupied \% & Private rented $\%$ & Social rented $\%$ & Other $\%$ \\
\hline Austria $^{3}$ & 56.9 & 40.3 & 2.8 & - \\
\hline Belgium $^{2}$ & 68 & 25 & 7 & - \\
\hline Denmark $^{4}$ & 50.6 & 17.8 & 27.2 & 4.4 \\
\hline Finland ${ }^{1}$ & 58 & 17 & 17 & 1 \\
\hline France $^{3}$ & 56 & 19.7 & 17.2 & 7.1 \\
\hline Germany $^{3}$ & 43 & 51 & 6 & - \\
\hline Greece $^{2}$ & 80.1 & 19.9 & - & - \\
\hline Ireland ${ }^{4}$ & 7.4 & 11 & 6.9 & 4.7 \\
\hline Italy ${ }^{2}$ & 80 & 16 & 4 & - \\
\hline Netherlands ${ }^{3}$ & 54.2 & 10.8 & 35 & - \\
\hline Poland ${ }^{3}$ & 55.2 & 0 & 22.8 & 21.5 \\
\hline Portugal $^{2}$ & 75.7 & 21 & 3.3 & - \\
\hline Spain ${ }^{2}$ & 81 & 9.7 & 1.6 & - \\
\hline Sweden ${ }^{3}$ & 38 & 22 & 24 & - \\
\hline United Kingdom ${ }^{2}$ & 69 & 9.3 & 20.8 & - \\
\hline
\end{tabular}

$1=1999,2=2001,3=2002,4=2003$

Source: Norris and Shiels (2004)

Table 2. Presence of insulation facilities in the Dutch social housing stock

\begin{tabular}{llllll}
\hline $\begin{array}{l}\text { Year of } \\
\text { construction }\end{array}$ & $\begin{array}{l}\text { \% of housing } \\
\text { stock }\end{array}$ & $\begin{array}{l}\text { Double glazing } \\
\%\end{array}$ & $\begin{array}{l}\text { Insulated } \\
\text { facade } \%\end{array}$ & $\begin{array}{l}\text { Roof insulation } \\
\%\end{array}$ & $\begin{array}{l}\text { Ground floor } \\
\text { insulation } \%\end{array}$ \\
\hline Until 1946 & 9.7 & 58 & 25 & 32 & 9 \\
$1946-1970$ & 35.5 & 61 & 34 & 38 & 6 \\
After 1970 & 54.8 & 79 & 82 & 85 & 59 \\
\hline
\end{tabular}

Sources: Ministry of VROM (2002) and CFV (2003) 
even larger when renewable energy concepts will be implemented in the existing stock on a large scale.

\section{THE EC DIRECTIVE ON THE ENERGY PERFORMANCE OF BUILDINGS}

A significant development for the energy policy of professional landlords is initiated by the EC in its Energy Performance of Buildings Directive (European Commission, 2003). The EPBD is a crucial part of the EC strategy to comply with the obligations regarding the Kyoto Protocol. Based on the $\mathrm{CO}_{2}$ reduction policy of the EC, targets have been set for the building sector. Aiming at building owners, an important objective of the EPBD is to promote the improvement of the energy performance of buildings within the European Community, taking into account outdoor climatic and local conditions, as well as indoor climate requirements and cost-effectiveness.

The member states of the EU have been obliged to implement the directive in their national legislation as from January 2006. Details of the implementation of the EPBD are left to the member states, allowing each member state to choose the regime that best addresses its specific national situation. The EPBD sets no mandatory measures; consequently the baseline for energy performance is current practice according to national policy.

The EPBD prescribes the use of an energy certificate, which gives insight in the current energy performance of a building and presents proposals for improvement of its energy performance. This energy certificate must be supplied at each transaction moment when a dwelling is build, sold or at turnover. Both new and existing buildings must be certificated.

In the Netherlands, the energy certificate prescribed by the EPBD is accompanied by an energy label for dwellings. Following the labelling used in household appliances, the en- ergy label for dwellings has a classification ' $\mathrm{A}$ ' to ' $G$ ', where a dwelling with energy label ' $A$ ' has the best energy performance.

Beerepoot and Sunikka (2005) judge the EC energy certificate to be essentially a communicative instrument that addresses information problems. Combining it with regulations or economic incentives will improve its effectiveness. Consequently, energy performance standards for existing dwellings may well become obligatory in due time, just as energy performance standards have become obligatory for new construction in many European countries.

The implementation of the EPBD entails opportunities for professional landlords. Firstly, they will gain a detailed insight in the energy performance of their housing stock, because they have to provide an energy certificate at turnover. This gives opportunities to integrate energy labelling in their strategic asset management as a basis for analysis and evaluation and the formulation of targets.

A second opportunity of the EPBD for professional landlords relates to the communicational value of the EPBD energy label. A professional landlord can employ the energy label as a basis for its communication with its stakeholders and tenants about energy conservation measures and energy performance. Especially the tenants play an important role in the appraisal of the EPBD energy labelling system. Therefore, the communication with tenants about energy performance should foremost be based on comfort, health, indoor climate and living expenses, because these aspects appeal to tenants more than the concept energy performance.

In addition, if energy performance standards for existing dwellings become obligatory as they are for new construction, professional landlords will have no choice but to take up energy as an integral part of their asset management. 


\section{STRATEGIC ASSET MANAGEMENT}

Professional landlords have to take decisions about the development of their housing stock in order to avoid voids, to keep their housing stock in line with the present and future tenants' demands and to keep their stock in a proper physical state. The importance of the development of policies and strategies supporting these decisions has grown considerably in many Western countries in the last 10 to 20 years, mainly due to the rise of neoliberalism and, in connection with that, diminished financial support from the government. This shift can particularly be observed in the social rented sector, which traditionally has been very government-dominated in most European countries. These developments have led to a more market oriented social housing management (Gruis and Nieboer, 2004).

Although strategic asset management in social housing is not restricted to Dutch housing associations only, the concept is in great length employed by the Dutch housing associations. This is to a large extent due to the characteristics and tasks of Dutch housing associations. When set within an international context, social rented housing in the Netherlands can be characterised by its relatively large share of the housing stock, a strong orientation on the market, a relatively large proportion of dwellings for middle-income households and, more or less as a consequence, a large variety of tenants in socio-economic respect (Van Kempen and Priemus, 2002; Priemus, 2003). With an asset of roughly one third of the total housing stock, Dutch housing associations own a considerable part of the total housing stock. They are not-for-profit organisations, which are obliged to operate in the interest of housing, in particular by providing decent, affordable housing to lower-income households.

During the last 10 years, Dutch housing associations were transformed from opera- tional, task-oriented organisations into 'social entrepreneurs' and had to operate in a more strategic, market oriented way. As a result, the sector is, more than in the past, responsive to innovations to support management decisions. This might create a favourable climate for the development of strategies on relatively new issues. Energy-efficient asset management can be seen as one of these.

The models for the development of asset management strategies are based on those for commercial companies. The core objectives of a commercial enterprise generally differ considerably from those of a housing association or another non-profit organisation, because of the relative importance of making profit. Nevertheless, the model from the commercial sector can be very useful for non-commercial landlords. An example of such a model is Kotler's (1997) general model for strategic business planning (see Figure 1).

More or less similar to this model is the strategic asset management model of Van den Broeke (1998), particularly developed for the social housing sector. Since van den Broeke has published his model, several variants have been produced (e.g. Nieboer et al., 2001) among others the one in Figure 2.

The model starts with the formulation of the mission and general objectives (mainly on the portfolio level) of the organisation. Based on these objectives and an analysis of internal and external factors, more specific targets and strategies (mainly on the housing estate level) are formulated. After this, a check or appraisal of the proposed strategies takes place. The assigned strategies are elaborated in estate management plans, after which the implementation takes place.

The formulation of strategies is an important aspect of the strategic asset management process. To define distinct strategy alternatives, the use of 'labels' has proven in our advisory practice at housing associations to be a very efficient way to allocate investments in 


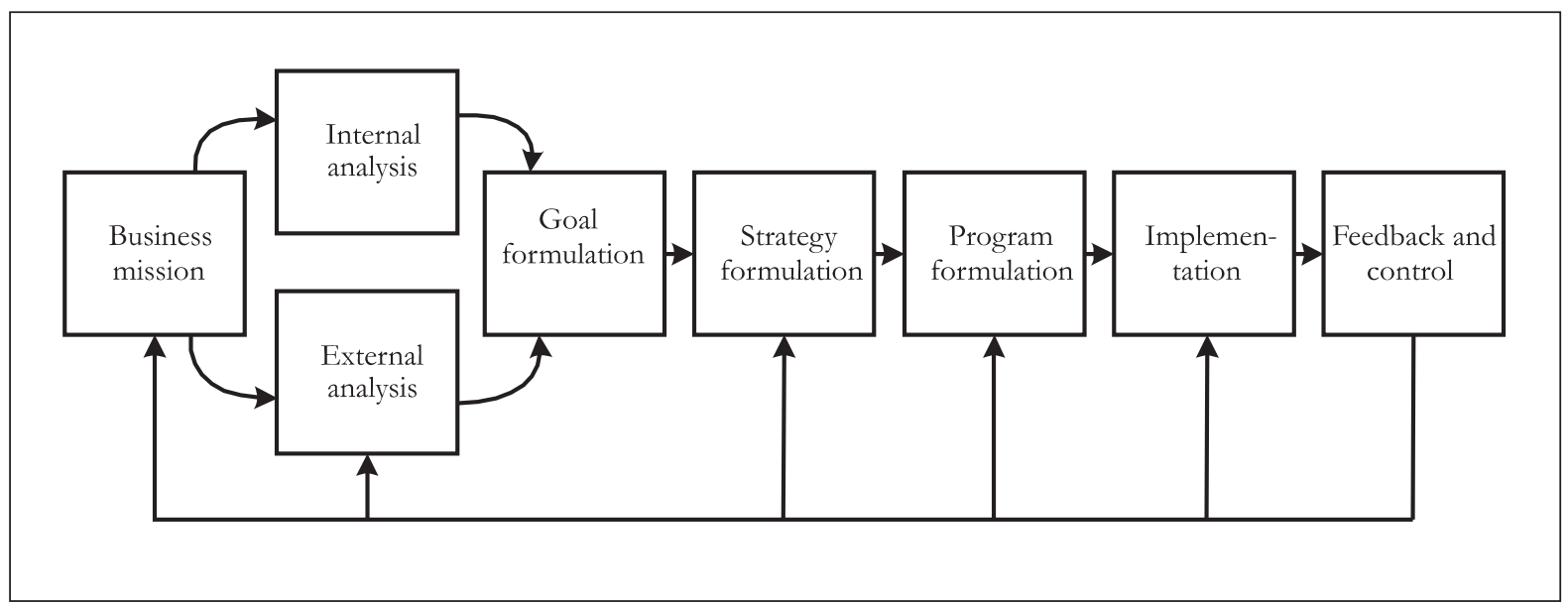

Figure 1. Model of the strategic business planning process

Source: Kotler (1997)

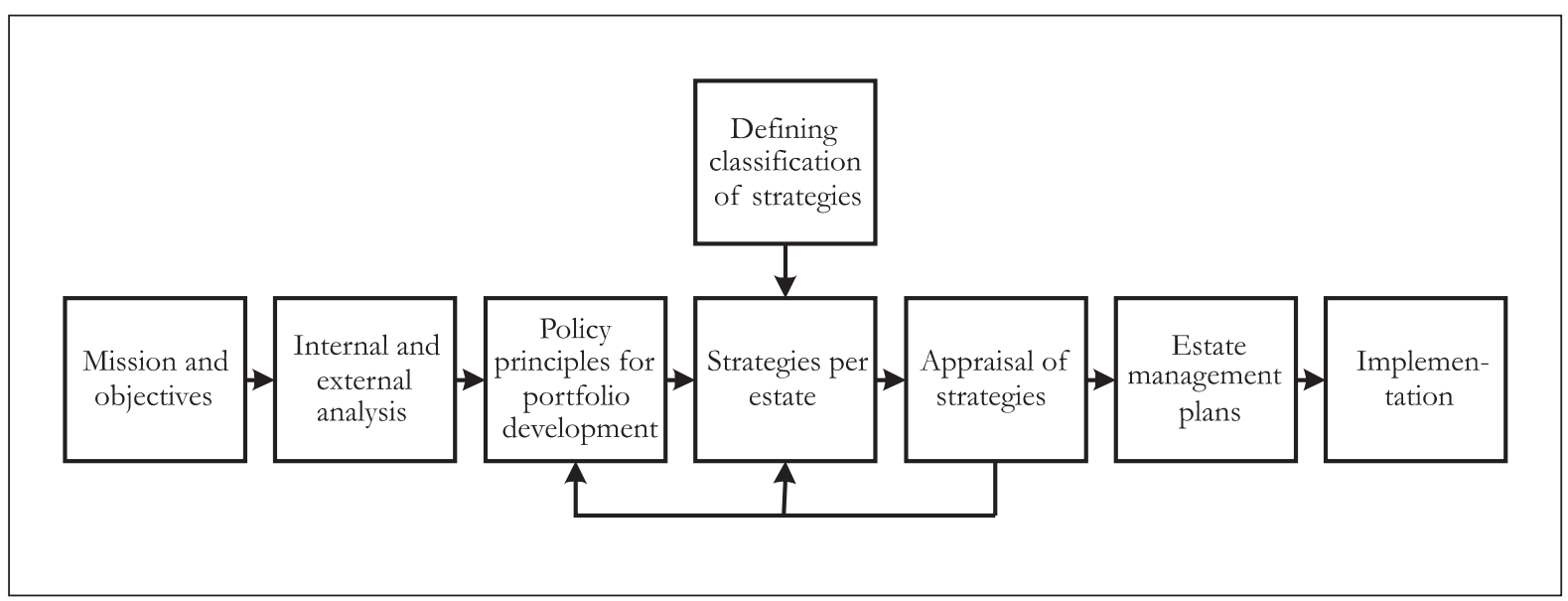

Figure 2. Model for developing asset management strategy

Source: based on Nieboer et al. (2001)

the housing stock. Two types of labels can be distinguished, whereby each type refers to either 1) measures or activities (indicating what has to be done) or 2) the desired quality or performance level (indicating what has to be achieved). The use of labels can provide housing associations with a clear and convenient grouping of measures and activities and/or quality and performance levels.
In general, labels are formulated per housing estate, although in some cases it might be necessary to define and employ labels on the level of individual dwellings, on neighbourhood level or the level of market segments (product-market combinations). An interesting discussion with regard to energy conservation is on what level of the housing stock the improvement of the energy performance should 
Table 3. Some relevant domains and examples of labels in each domain

\begin{tabular}{|c|c|c|}
\hline Domain & Examples of labels & Examples of actual measures \\
\hline Physical modification & Renovation $^{1}$ & $\begin{array}{l}\text { Merge dwellings, place rooftop } \\
\text { apartments }\end{array}$ \\
\hline Technical quality & $\begin{array}{l}\text { Upgrade maintenance level }{ }^{2} \text {, } \\
\text { decrease maintenance level }{ }^{2}\end{array}$ & Replace roofing, change facade \\
\hline Eventual disposal & Sale $^{1}$, demolition ${ }^{1}$ & $\mathrm{~N} / \mathrm{a}$ \\
\hline Lettability and target group & $\begin{array}{l}\text { Redevelopment for specific target } \\
\text { group (for instance the elderly) }{ }^{1}, \\
\text { allocate for lowest income groups }{ }^{1}\end{array}$ & $\begin{array}{l}\text { Place elevator (target group the } \\
\text { elderly), decrease rent level }\end{array}$ \\
\hline Energy performance & $\begin{array}{l}\text { EPBD label 'D' } 2 \text {, quality level of } \\
\text { indoor climate }{ }^{2}\end{array}$ & $\begin{array}{l}\text { Replace open heater by central } \\
\text { heating, place double glazing, } \\
\text { improve insulation level }\end{array}$ \\
\hline
\end{tabular}

1 = label indicating measure or activity, 2 = label indicating desired quality or performance level

be performed. On the one hand, a professional landlord can choose to suit the wishes of its individual tenants, resulting in an increased willingness to collaborate but also in a variety of measures, on the other the housing association can choose to renovate on housing estatelevel in order to decrease costs and simplify construction processes (Straub and Vijverberg, 2004).

Labels must refer to topics that are considered as relevant and important for the housing stock. Examples of these domains with examples of labels and actual measures are listed in the Table 3.

The level of detail of the labels can vary. It is important to choose the right level of abstraction. On the one hand, labels are meaningless when they are very general, while on the other hand, very detailed labels make stock policy inflexible. In practice, most labels are rather general in the first stages of policy development, and will be elaborated in the implementation phase. Examples of rather general labels are maintain, refurbishment, sale and demolition. More detailed labels can be made by defining items as specific maintenance and rent levels.

As we have seen, two types of labels can be distinguished. Labels according to the first type (measures or activities) that refer to energy conservation indicate the measures that must be taken to achieve a certain energy performance. Labels of the second type, addressing the desired quality or performance level, are especially interesting in the context of this paper, because they refer to the use of energy labels according to the EPBD as well as to aspects resulting from energy conservation measures.

The labels related to energy performance can be defined in strict accordance with European or national regulations (for instance performance level A, B, C, D etc.). Labels for convenience and luxury are appropriate examples concerning the aspects resulting from energy conservation measures. In this approach, not the energy performance itself (i.e. EPBD energy label) but related aspects like comfort level, security, health and indoor climate could find a place. For example, the placement of $\mathrm{HR++}$ glazing improves the energy performance but also increases the comfort level and the security level of the dwelling, just as the replacement of an open heater by a high efficiency boiler will improve the energy performance but also improves the indoor climate and the health level of the dwelling. 


\section{INTEGRATION IN STRATEGIC ASSET MANAGEMENT}

The strategy, on which the measures that eventually will be implemented are based, is developed in the consecutive steps of the strategic asset management process. In each step, specific information is required and drawn into the decision-making. Labels are employed in the central process-steps where the strategy options per housing estate are determined and its consequences are weighed. When we follow the steps of the strategic asset management process, the following information and considerations could be involved.

\section{- Mission and objectives}

In this first step, the framework for the deployment and implementation of energy conservation measures in relation to strategic asset management is drawn. The professional landlord determines its position towards energy conservation or, in a wider perspective, to sustainable building and sustainable management.

A stakeholder analysis could be beneficial to formulate a mission statement, of which the environmental aspirations are part. In this analysis, internal key departments such as strategy, maintenance/project development, communication and finances as well as external stakeholders such as tenants, the local community and regional collaboration forms can be consulted.

The mission statement needs to be translated into corporate objectives, which together form the framework for all activities of the professional landlord and, therefore, for its strategic asset management.

\section{- Internal and external analysis}

The objectives that have been formulated in the previous step, serve as a handle for the in- formation that will be drawn into the analysis.

An important first step in the analysis is to gain insight in the energy performance of the entire stock on the level of the individual dwellings. Now that the EPBD has been enforced in the European countries, every transaction in the professional landlord's stock adds to his energy performance dataset. However, depending on the turn over rate of his housing stock, it may take a considerable time before data on the energy performance of the entire stock will be available. It might, therefore, prove to be beneficial to calculate the EPBD energy label of the dwellings by using reference dwellings that represent the characteristics of each dwelling type in the stock. A simple approach to define the set of reference dwellings, is to develop a matrix with a division upon dwelling type (for instance detached, single family, multi family without elevator, multi family with elevator, high rise) in combination with a division upon year of construction, with the timeframes roughly based on building construction and step-wise improvements of the energy performance resulting from the introduction of innovations (such as insulation, high efficiency boiler). The reference dwellings can be used to assess not only the EPBD energy label, but also the average energy costs for heating/cooling and hot water production per dwelling and the $\mathrm{CO}_{2}$ emission and gas use per dwelling.

The data can be used as input for a portfolio analysis of the stock, similar to employing portfolio analysis for analysing other performances of the stock as has been described by Van der Flier and Gruis (2002). With the portfolio analysis, housing estates that show a deviating performance, and consequently may need attention, can be selected. The portfolio analysis can be based on indicators such as:

- energy costs versus rent level;

- affordability versus EPBD energy label;

- turnover rate versus EPBD energy label; 
- acceptance rate versus EPBD energy label;

- vacancy rate versus EPBD energy label.

In addition to the portfolio analysis, it may be useful to gain insight in other subjects regarding energy performance, such as:

- the effectiveness of potential measures/ investments;

- the costs of these investments to improve the energy performance of the stock;

- the willingness of the tenants to contribute financially to these investments, for instance by a rent increase;

- (other) possibilities to finance the improvement costs (subsidies, outsourcing, etc.).

\section{- Policy principles for portfolio development}

Now the corporate objectives have been formulated and the results of the analysis are on the table, this information is weighed and structured, thus forming the basis for defining the set of labels and the housing estate strategies.

In this step, concrete targets are formulated. The EPBD energy labelling provides a very effective means to formulate targets upon, for instance "The average energy performance of the stock has to meet at least EPBD energy label C within XX years" or "No dwelling in the housing stock will have an energy performance less than label D in the year XX". Another example is "The total contribution of our housing stock to a reduction of $\mathrm{CO}_{2}$-emission should be XX ton in the year YY", but one could of course also formulate targets with regard to subjects such as comfort level, gas usage, energy costs in relation to the rent, health or indoor climate.

\section{- Defining classification of strategies and} Strategy options per housing estate

Based on the previous steps, a classification of possible strategy options is performed in order to define the specific sets of labels that will be employed in these steps.

Subsequently, depending on the specific level, the dwellings, housing estates, neighbourhoods and/or market segments are attributed one or more labels to determine their strategy. This step could be seen as the core of the strategic asset management, because by labelling the individual housing estates, the future of the housing association's total housing stock is decided upon.

The choice of one label can depend on the choice of another label. For instance, if demolition is foreseen within 5 years for a certain housing estate, it has no use to aim at a large improvement of energy performance. If a significant improvement of the indoor climate is desired, 'maintain as is' of the particular housing estate is an unlikely option.

Especially with regard to energy conservation, it could be beneficial to determine the end situation (i.e. the EPBD energy label) and the necessary process as separate entities. Amongst different housing estates the label indicating an end situation may be similar (for example the same energy label) but the strategy to accomplish this label may vary between the housing estates. This situation occurs if, for instance, the tenant group of one housing estate has other demands than the tenant group in an other housing estate, or the technical requirements of an housing estate demand other technical solutions to achieve the target, resulting in other pay-back times.

\section{- Appraisal of strategy options}

The strategies that have been assigned need to be evaluated in order to determine their contribution to the corporate objectives and their 
consequences in terms of energy performance, affordability, size and diversity of the total housing stock and the financial continuity of the housing association. It should, for example, be prevented that an improved overall energy performance results in a significant reduction of the affordability or solvency.

\section{- Estate management plans and Implementation}

In the remaining two steps of the asset management model, the housing estate strategies are translated in actual measures, which will be implemented according to the housing estate management plans. In this last phase of the strategic asset management, the actual energy efficiency is realised through taking measures that improve the energy performance of the dwellings.

In section 4 , we indicated the possibility to define and employ labels on the level of the dwelling, housing estate, neighbourhood and market segment. Straub and Vijverberg (2004) indicate that, when implementing improvements - which energy efficiency measures usually are - professional landlords have a number of options regarding:

- the scale and time of the intervention (building block at once or per individual dwelling);

- the occupancy status (when occupied, move present tenants to temporary housing or at turnover);

- the initiative (housing association or tenant(-sgroup));

- freedom of choice for the tenants.

In the final step of the energy-efficient asset management process, the general policy regarding energy performance can be put down in an energy policy plan, possible as part of a sustainable management plan. These documents facilitate internal implementation of the strategies and the communication with the stakeholders.

\section{CASE STUDIES}

In this section, the energy conservation activities of three Dutch housing associations are analysed against the background of their strategic asset management. The three case studies have been selected based on the distinct approach each of the housing associations employs towards asset management and energy conservation. The case studies are based on interviews with responsible members of staff of each housing association and a desk study of the relevant documents of the housing associations such as year reports, environmental policies and corporate brochures.

\section{WonenBreburg}

WonenBreburg is a housing association with an asset of 26.830 dwellings, mainly in the cities of Tilburg and Breda. WonenBreburg employs a staff that together equals 393 full time equivalents (WonenBreburg, 2007).

An important incentive for WonenBreburg's energy efficiency activities is the Energy Covenant, whichit has drawn up together with the Municipality of Tilburg and three other housing associations for the period 2006-2011. In the covenant, the parties have assigned high priority to energy efficiency and reduction of $\mathrm{CO}_{2}$ emissions, in particular aimed at existing housing. The covenant includes targets regarding the implementation of the EPBD legislation and influencing the energy related behaviour of occupants (Tilburgs Energie Convenant, 2006).

WonenBreburg distinguishes 4 general strategy labels for its housing stock: maintain, improve, sale, and demolition. For the housing estates that have been assigned the label maintain or improve, WonenBreburg develops its strategic asset management by matching housing supply and demand. A set of specific markets is distinguished, by determining the relevant target groups and analysing their spe- 
cific demands. By matching these markets to the characteristics and qualities of the individual estates, an optimal fit between market segment and housing estate is aimed for. In order to be able to perform this match, a set of 26 reference dwellings is used to map the characteristics of the dwellings in the housing estates. When a good match between market segment and housing estate is found, the actual measures for the estate are based on potential improvements, which are listed for each reference dwelling. In this phase, specific attention is paid to energy efficiency (WonenBreburg, 2007).

WonenBreburg gives priority to those strategies that result in a profitable exploitation of the housing stock and an increase in its market value. Nevertheless, WonenBreburg does invest in energy conservation and a considerable share of this investment volume is unprofitable. On the one hand, WonenBreburg realises with these investments its energy conservation ambitions. On the other hand, WonenBreburg takes into account the possibility that forthcoming changes in legislation may help to increase the profitability of earlier energy conservation investments and the possibility that an improved energy performance may have a positive effect on the future market value of their dwellings.

The energy performance of an estate is taken into account when deciding upon its strategy, albeit that it is never as decisive as economical considerations are. However, energy performance plays a more important role in determining the maintenance and project planning: an estate with a low energy performance is likely to be advanced in the planning.

\section{Staedion}

Staedion is a housing association that is active in the city of The Hague, in the western part of the Netherlands. It has an asset of 32.472 dwellings. Staedion employs a staff that equals 396 full time equivalents (Staedion, 2007a).

Staedion mentions sustainability among its corporate objectives and this objective is elaborated in its environmental policy (Staedion, 2007b). The central objective of this environmental policy is to "achieve sustainable goals through an as clean as possible management of the housing stock". In its environmental policy, Staedion distinguishes three main themes: sustainability, liveability and health. While sustainability aims at goals for the long term, the other two themes focus on the "here and now". In order to realise the three main themes within a timeframe of 5 years, 10 priorities have been appointed, addressing amongst others sustainable building and maintenance, reduction of $\mathrm{CO}_{2}$ emissions, energy and water saving, tenant participation and indoor climate. Each of the 10 priorities is described in terms of targets, measures, monitoring and evaluation. Regarding the priority that addresses the reduction of $\mathrm{CO}_{2}$ emissions and energy conservation, Staedion follows the sector agreement that aims at a reduction of gas use of $20 \%$ from 2008 to 2018. Additionally, Staedion studies the implementation of renewable energy sources, in specific geothermal installations, and undertakes feasibility studies for wind energy and the use of photovoltaic panels in forthcoming renovation projects.

Staedion develops its strategies on the level of the neighbourhood, taking into account the local and regional housing market, local (health) care and related services, the social situation in the neighbourhood, financial possibilities, the activities and plans of other housing associations in that neighbourhood and the local political context. Despite Staedion's elaborate environmental policy and guidelines for its implementation in practice, the energy performance of the stock is not considered in Staedion's strategy development on neighbourhood level. 
Table 4. The relation between exploitations period, exploitation strategy and ambition level of housing association Staedion

\begin{tabular}{|c|c|c|}
\hline $\begin{array}{l}\text { Exploitation } \\
\text { period }\end{array}$ & Exploitation strategy labels & Ambition level \\
\hline 5 years & $\begin{array}{l}\text { Reduce - no improvements, the maintenance level will be } \\
\text { limited to the most necessary measures only. }\end{array}$ & level 1 \\
\hline 10 years & $\begin{array}{l}\text { Maintain physical state - only measures that maintain the } \\
\text { present physical state are taken. }\end{array}$ & level 2 \\
\hline $15+$ years & $\begin{array}{l}\text { Maintain price-quality level - aimed at maintaining the present } \\
\text { price-quality level, therefore improvements are considered if, for } \\
\text { example, necessary to fulfil demands from the target group. }\end{array}$ & level 3 \\
\hline 25 years & $\begin{array}{l}\text { Extended exploitation - large improvements and renovation, in } \\
\text { order to secure lettability for the long term. }\end{array}$ & level 4 \\
\hline $25+$ years & $\begin{array}{l}\text { Restructure - usually implies demolition and new construction, } \\
\text { although reuse of the main building structure is considered if a } \\
\text { quality level that resembles new construction can be achieved. }\end{array}$ & level 5 \\
\hline
\end{tabular}

Source: Staedion (2005)

In general, when deciding upon the future of its existing housing stock, Staedion employs 5 different labels in its exploitation strategy (see Table 4), and the additional labels new construction and sale. Each of the 5 exploitation labels pairs with a specific exploitation period and a so called ambition level: a detailed description of the appropriate maintenance level and possible improvements.

The exploitation period takes a central position in the strategic asset management of Staedion. On the one hand, the administrative remaining exploitation period based on an economical lifespan of 50 years, can be used to determine the appropriate ambition level. On the other hand, a specific exploitation period can be assigned to a housing estate, overruling the remaining exploitation period. This last option is most likely to be used with the strategies extend exploitation and restructure.

Although energy conservation does not play an important role in the middle steps of the strategic asset management (strategy development) of Staedion, it does play a significant role in the last steps of its strategic asset management. In these last steps, the strategy is translated into projects and maintenance ac- tivities. Staedion's program for the existing stock plays an important role in this translation (Staedion, 2005). In this program, for each of the 5 ambition levels, detailed measures, materials and activities concerning maintenance and possible improvements are listed. The higher the ambition level, the more emphasis is placed on extending the exploitation period by improving the quality and the more energy conservation measures, sustainable materials and renewable energy concepts can be taken into account, because their payback time is secured. For example, repair of broken glass in the facade of a housing estate with a remaining exploitation period of 5 years (ambition level 1) will not result in an improvement, while in this situation in a housing estate with an exploitation period of $15+$ years (ambition level 3), high insulating HR+ glass will be installed, regardless of the replaced type of glazing (Staedion, 2005).

\section{Oost Flevoland Woondiensten}

Oost Flevoland Woondiensten (OFW) is a housing association that has an asset of 4.011 dwellings in and around the city of Dronten, 
in the province of Flevoland in the central part of the Netherlands. OFW employs a number of staff that equals 51 full time equivalents (OFW, 2007a)

In its corporate presentation as well as in many of its activities, OFW emphasises sustainable development and its responsibility for energy conservation and decreasing living costs, which has resulted in a more or less 'green' image. As from 2006, OFW has EPBD energy labels available for each of their dwellings, making OFW the first housing association in the Netherlands to have labelled its stock by employing EPBD energy labels.

Sustainability and energy conservation are included in the mission/vision and corporate objectives of OFW. In its policy plan (OFW, 2007b), OFW presents targets for its housing stock regarding the use of sustainable material, energy conservation and stimulating awareness at the side of the tenants, such as:

- In 2012 no dwelling has an EPBD label below label ' $\mathrm{D}$ '.

- In 2012 a reduction of $30 \%$ in gas use will be achieved compared to the year 2000.

- The trend in gas use will be made visible for each dwelling.

- Existing dwellings have at least EPBD label 'B' after renovation.

In renovation or new construction projects, OFW aims at an optimal energy performance within its financial possibilities. An improvement in energy performance generally results in a decrease of total livings costs, which is an important aim for OFW. Therefore, when determining which housing estates are to be renovated, OFW gives priority to those housing estates that have a low energy performance, in order to be able to decrease living costs for the tenants in concern. In this respect, OFW uses EPBD labels as a basis for its analysis and strategy development. Additionally, the rent policy of OFW prescribes that the yearly rent increase of dwellings with a low energy performance (EPBD label ' $\mathrm{E}$ ', 'F' or 'G') is reduced with $0,5 \%$.

OFW uses EPBD energy labels in the advertisements of vacant dwellings. At turnover, the new tenant is presented the EPBD energy label for the dwelling concerned. The EPBD energy label is accompanied by an estimation of the gas use (and costs) based on the average use of the dwelling, giving the tenant a clear insight in the average net living costs for that dwelling. Additionally, OFW informs its tenants about the possibilities they have to save energy by changing their energy related behaviour in their dwellings and by buying energy efficient equipment and appliances. OFW considers informing its tenants as good a means to save energy as physical measures in dwellings.

Regarding its organisation, OFW has a strong focus on creating commitment among the staff for the sustainable mission of OFW. This results from the notion that without commitment and dedication from its own staff, OFW won't be able to achieve its sustainable ambitions.

\section{DISCUSSION AND CONCLUSIONS}

Professional landlords can significantly contribute to governmental environmental policies by improving the energy performance of their housing stock. In order to effectively and efficiently improve the energy performance of the stock without sacrificing other objectives, energy conservation should be integrated in all phases of the strategic asset management process. With professional landlords facing tightening energy performance requirements, the EPBD legislation could be considered as an opportunity and, at the same time, a means for professional landlords to incorporate energy conservation in their strategic asset management. Implementing the EPBD energy labelling in asset management of professional land- 
lords implies the use of EPBD energy labels. In the Netherlands, the use of this type of labels has just started, but experience in the social rented sector with other types of labels has proven to be a great help in portfolio development and the management of housing estates.

In this paper, we have presented a method to integrate energy conservation in the asset management of professional landlords. This method uses EPBD energy labels as a means to establish integration of energy conservation in the individual steps of the asset management process.

From the case studies, we learn that the housing associations WonenBreburg, Staedion and Oost Flevoland Wonen (OFW) each show a distinct approach towards energy conservation. WonenBreburg takes an economical perspective towards energy conservation, Staedion has an elaborated policy and program for the actual realisation through concrete measures in its existing stock and OFW has tightly integrated energy conservation in many of its organisational processes and focuses on lowering living costs and offering clear information for its tenants.

From 2008 onwards, Dutch housing associations are obliged to provide an EPBD energy performance label at transaction moments and, as a result, their database with energy performance data of their housing stock will grow in the years following. There are signals from the Dutch social housing sector that, currently, the housing associations tend to show a pragmatic attitude and shift the formulation of energy conservation targets based on EPBD energy labels forward until they have sufficient insight in the energy performance of their housing stock. Consequently, the implementation of the EPBD energy labels in their asset management is likely to gradually increase after the energy performance data has come available.

At Staedion and WonenBreburg a similar attitude can be observed as both housing associations have integrated energy conservation in several steps of their asset management process (i.e. goal formulation and determining and implementation of the actual measures). However, EPBD energy labels seem to play, as yet, a minor role in these processes. Additionally, in the analysis and strategy development of Staedion and WonenBreburg, other considerations seem to be far more decisive than energy conservation, if energy conservation is considered at all. This is remarkable taking into account that Staedion and WonenBreburg have formulated sound objectives regarding energy conservation and do actually implement energy conservation measures in their maintenance and project practice.

OFW, on the contrary, has integrated the EPBD energy labelling firmly in most steps of its asset management process and, therefore, can be qualified as an early market actor in adopting the EPBD energy labelling. The typical characteristics of housing associations that are early market actors in adopting energy conservation measures and innovations, which have been by described by Egmond et al. (2006), can be observed at OFW, such as a high internal motivation, basing innovations on strategic decisions and a visionary attitude.

An obvious simple possibility is to use EPBD labels as an instrument for communication, as is done by OFW when offering vacant dwellings to potential tenants. This can raise their awareness about energy consumption and influence their behaviour regarding energy consumption, but it does not improve the energy efficiency of the housing stock. In addition, in areas where voids are rare, nearly all dwellings, including those with low energy efficiency, are rented anyway. So, energy policy of landlords always needs to include ambitions not only to influence housing demand, but also to influence housing supply.

In connection with the latter, the case studies show that a direct use of the EPBD labels 
might not be sufficient for a fruitful incorporation of energy conservation in asset management. Results indicate that a kind of translation might be necessary for an effective implementation in current policies of professional landlords. From the case studies, examples of such a translation can be drawn. WonenBreburg tries to translate energy efficiency into (increased) market value, although currently done in an implicit way. Staedion regards technical energy-saving options as a means to improve the technical quality of its housing stock. OFW tries to translate energy-efficiency into lowering energy costs for the tenants.

Apparently, lettability, market value, affordability and technical quality are the central policy areas in the asset management of these housing associations, which may act as a framework within which energy conservation strategies and measures will be judged. For these organisations, further research into the relationship between these areas on the one hand and the energy performance of a dwelling on the other may be very helpful. Additionally, further research is necessary to find solutions for the present barriers that professional landlords face when improving the energy performance of their housing stock. In this respect, research aimed at solving the financial and economical barriers, for example research focussing at profitable exploitation of renewable energy concepts, or research focussing at outsourcing and third party financing possibilities, looks very promising.

\section{REFERENCES}

Beerepoot, M. and Sunikka, M. (2005) The contribution of the EC energy certificate in improving sustainability of the housing stock, Environment and Planning B-Planning \& Design, 32(1), pp. 21-31.

CFV (2003) Verslag financieel toezicht woningcorporaties 2003 [Report of financial supervision housing associations 2003], Naarden: Centraal Fonds voor de Volkshuisvesting. (In Dutch)
Ecofys (2005) Kosteneffectieve energiebesparing en klimaatbescherming - de mogelijkheden van isolatie en de kansen voor Nederland [Cost-effective energy conservation and climate protection - the possibilities of insulation and the opportunities for the Netherlands], Utrecht: Ecofys the Netherlands. (In Dutch)

Egenhofer, C., Jansen, J.C., Bakker, S.J.A. and Jussila Hammes, J. (2006) Revisiting EU policy options for tackling climate change - A social cost-benefit analysis of GHG emissions reduction strategies. Brussels: Centre for European Policy Studies.

Egmond, C., Jonkers, R. and Kok, G. (2006) Target group segmentation makes sense: if one sheep leaps over the ditch, all the rest will follow, Energy Policy, 34(17), pp. 3115-3123.

European Commission (2003) Energy Performance of Buildings Directive (EPBD) - Directive 2002/ 91/ec of the European Parliament and of the Council of 16 December 2002 on the energy performance of buildings, European Commission.

Gruis, V. and Nieboer, N. (2004) Strategic housing management: an asset management model for social landlords, Property Management, 22(3), pp. 201-213.

Healy. J.D. and Clinch, J.P. (2004) Quantifying the severity of fuel poverty, its relationship with poor housing and reasons for non-investment in energy-saving measures in Ireland, Energy Policy, 32(2), pp. 207-220.

Howden-Chapman, P., Matheson, A., Crane, J., Viggers, H., Cunningham, M., Blakely, T., O'Dea, D., Cunningham, C., Woodward, A., Saville-Smith, K., Baker, M., Waipara, N., Kennedy, M. and Davie, G. (2004) Retrofitting houses with insulation to reduce health inequalities: a community-based randomised trial, Paper presented at Second WHO Conference on Housing and Health, Vilnius, Lithuania, October 2004.

Kotler, Ph. (1997) Marketing management. 9th edition. New Jersey: Prentice Hall International.

Milne, G. and Boardman, B. (2000) Making cold homes warmer: the effect of energy efficiency improvements in low-income homes, Energy Policy, 28(6), pp. 411-424.

Ministry of VROM (2002) Energie besparingsmaatregelen in de woningvoorraad; KWR 2000 maakt balans op [Energy conservation measures in the housing stock; KWR 2000 weighs 
pros and cons], The Hague: Ministerie van Volkshuisvesting, Ruimtelijke Ordening en Milieubeheer. (In Dutch)

Nieboer, N., Heeger, H. and Van der Haak, M. (2001) Strategisch voorraadbeleid: een ontwikkelingsmodel [Strategic asset management: a model for development], Real Estate Magazine, 4(16), pp. 51-55. (In Dutch)

Norris, M. and Shiels, P. (2004) Regular National Report on Housing Developments in European Countries. Dublin: Department of the Environment, Heritage and Local Government.

OFW (2007a) Jaarverslag 2006 [Year report 2006], Oost Flevoland Woondiensten, Dronten. (In Dutch)

OFW (2007b) Duurzaam bouwen aan goed wonen [Sustainable building for good housing], Oost Flevoland Woondiensten, Dronten. (In Dutch)

OFW (2006) Oost Flevoland Woondiensten \& Duurzaam ondernemen [Oost Flevoland Woondiensten \& Sustainable management], Oost Flevoland Woondiensten, Dronten. (In Dutch)

Petersdorff, C., Boermans, T., Harnisch, J., Stobbe, O., Ullrich, S. and Wartmann, S. (2005) CostEffective Climate Protection in the EU Building Stock. ECOFYS Germany.

Priemus, H. (2003) Dutch housing associations: current developments and debates, Housing Studies, 18(3), pp. 327-351.

Staedion (2005) Programma van eisen bestaande bouw [Program of demands for the existing housing stock], Staedion, Den Haag. (In Dutch)

Staedion (2007a) Jaarverslag 2006 [Year report 2006], Staedion, Den Haag. (In Dutch)
Staedion (2007b) Milieubeleidsplan 2007-2011 [Environmental policy 2007-2011], Staedion, Den Haag. (In Dutch)

Straub, A. and Vijverberg, G. (2004) New strategies for housing quality improvement by Dutch Landlords, Open House International, 29(3), pp. 38-44.

Van den Broeke, R.A. (1998) Strategisch voorraadbeleid van woningcorporaties: informatievoorziening en instrumenten [Strategic asset management of housing associations: information providing and instruments], Delft: Delft University Press. (In Dutch)

Van der Flier, K. and Gruis, V. (2002) The applicability of portfolio analysis in social management, European Journal of Housing Policy, 2(2), pp. 183-202.

Van Kempen, R. and Priemus, H. (2002) Revolution of social housing in the Netherlands: possible effects of new housing policies, Urban Studies, $39(2)$, pp. 237-253.

Verbeeck, G. and Hens, H. (2005) Energy savings in retrofitted dwellings: economically viable? Energy and Buildings, 37(7), pp. 747-754.

Wiesenthal, T., Fernandez, R., Taylor, P. and Greenleaf, J. (2006) Energy and Environment in the European Union - Tracking progress towards integration, EEA Report No 8/2006, European Environment Agency, Copenhagen, Denmark.

WonenBreburg (2006) Derde energieconvenant Tilburg [Third energy covenant of Tilburg], Tilburg. (In Dutch)

WonenBreburg (2007) Jaarverslag 2006 [Year report 2006], WonenBreburg, Tilburg. (In Dutch)

\section{SANTRAUKA}

\section{PROFESIONALIEMS NUOMOTOJAMS: TURTO VALDYMAS EFEKTYVIAI VARTOJANT ENERGIJA}

\section{Jan-Willem SMID, Nico NIEBOER}

$\mathrm{CO}_{2}$ mažinimas taupant energiją - svarbi tema dažnoje valstybinejje aplinkos apsaugos politikoje. Kadangi naujos statybos sudaro tik mažą visų pastatų išteklių dalị, jau pastatytų būstų energinis naudingumas labai svarbus. Profesionalių nuomotojų vaidmuo taupant energiją gali būti svarbus, tačiau yra ženklų, kad didžiulis jų turimų jau pastatytų būstų energijos taupymo potencialas išnaudojamas nedaug. Šiame darbe pristatomas metodas, kaip energijos taupymo temą įtraukti į profesionalių nuomotojų turto valdymą, kad energijos taupymas taptų jų priežiūros ir renovacijos praktikos dalis. Metodo aprašymas remiasi Olandijos socialinio būsto savininkų turto valdymo praktika, bet jis gali būti naudingas ir kitiems profesionaliems nuomotojams. Metodas pagrịstas Europos EPBD (Direktyva dẻl pastatų energetinio naudingumo). 